\title{
1. World at a tipping point
}

The liberty of a democracy is not safe if the people tolerate the growth of private power to a point where it becomes stronger than their democratic state itself. That, in its essence, is fascism - ownership of government by an individual, by a group, or by any other controlling private power. Among us today a concentration of private power without equal in history is growing.

Franklin D. Roosevelt

\section{INTRODUCTION}

The global ecological crisis, on the one hand, and responses from nationstates to deal with it, on the other, are in complete disconnect. States and governments seem mere bystanders, unable, perhaps unwilling, to reclaim the commons and revert the forces of human self-destruction. They no longer govern. Rather, our democratically elected governments are caught up in crisis management with no signs of vision and direction. Are we seeing the end of functioning democracies on a global scale?

The critique of the democratic deficit of international law and governance is not new, ${ }^{1}$ but it has never gathered more intuitive plausibility than now in an age of global warming. The impacts of climate change are all around us. Although the knowledge of an emerging ecological crisis is at least 40 years old, political leaders and the state-centred structure of international governance appear incapable of responding to it in an effective way: there is not only a democratic deficit but an ecological deficit as well.

The democratic and ecological deficits of international politics could have common ground though. ${ }^{2}$ At international level the nations' representatives conventionally find themselves in a bargaining situation and

1 See, for example, Steven Wheatley, The Democratic Legitimacy of International Law (Hart Publishing, 2010).

2 See Vandana Shiva, 'The Greening of the Global Reach', in Wolfgang Sachs (ed.), Global Ecology: A New Arena of Political Conflict (Zed Books, London 1993): 155; Walter F. Barber and Robert V. Bartlett, Global Democracy and Sustainable Jurisprudence: Deliberative Environmental Law (The MIT Press, Cambridge/London 2009): 5; 'Earth Convention' (Democracy Convention, 2013): http://democracyconvention.org/focus-area/earth-democracy. 
entangled in a situation of anarchy between states. National interests trump any sense of the common good. Such a rational choice perspective can hardly be democratic as it neither reflects a global nor a local perspective. At a global level, we are confronted with egos unable to see their collective destiny. From a local perspective, nations and their representatives rarely connect with the affected people, especially if they live in different countries. The ever-increasing gap between the rich North and the poor South is a direct result of the failure of state-centred governance. ${ }^{3}$

The antithesis of state-centred governance is earth-centred governance, or earth governance for short. If we start our thinking about and around global governance from the perspective of earth, we see the whole first, not its parts. The needs of earth and all her inhabitants stand right before us. They define the ends of action for which we must find the means. In this pursuit, states are means, not ends in themselves. It is wrong to believe that states define the means and ends of global governance. They can only ever be instruments (means) of people (earth's inhabitants) who ultimately define the purpose (ends) of human action. Earth governance describes a new starting point, a new goal and new ways to get there.

Essentially, earth governance is the epitome of people taking responsibility for the lives of all beings. A strong expression of this sense of responsibility can be found in the Earth Charter. The Earth Charter provides an ethical framework for global governance, a new covenant between humans and nature. In part IV, 'Democracy, Nonviolence, and Peace', it states four principles aiming at a democratic culture for sustainable governance: ${ }^{4}$

1. to strengthen democracy at all levels (including transparency, accountability, participation and access to justice);

2. to integrate the required capabilities for a sustainable way of living in a process of lifelong learning;

3. to treat all living beings with respect and consideration;

4. to promote a culture of tolerance, nonviolence, and peace. ${ }^{5}$

3 Klaus Bosselmann, 'Towards Multilevel Governance for Sustainability: Trends and Challenges', in Contested Futures: Sustainability, Governance and International Human Rights (Europe - New Zealand Research Series Paper, 2010): $1,11,26$.

4 See also Klaus Bosselmann, J. Ronald Engel and Prue Taylor, Governance for Sustainability: Issues, Challenges, Successes (IUCN Environmental Policy and Law Paper No. 70, 2008).

5 For further democratic implications of the Earth Charter, see J. Ronald Engel, 'The Earth Charter as a New Covenant for Democracy', in Klaus Bosselmann and J. Ronald Engel (eds), The Earth Charter: A Framework for Global Governance (KIT Publishing, Leiden 2010): 29-40. 
The current ecological crisis has been scientifically examined and politically discussed for over 40 years. ${ }^{6}$ Several international meetings have taken place and some of them have resulted in soft law documents such as agreements, conventions, treaties, etc. So far, only one global treaty actually sets out targets and timetables, that is, the Kyoto Protocol. ${ }^{7}$ Although the Kyoto Protocol is flawed both in content and execution, it represents the first international attempt at practical action to tackle one serious threat of the ecological crisis (global warming). Nothing comparable can be said about the international regime for biodiversity protection that lacks any specific rules and enforcement mechanisms. The widely perceived failure of international environmental agreements defies a notable consensus between scientists and politicians that humanity is quickly facing - or already experiencing ecological tipping points. ${ }^{8}$

It looks as if the worsening of the ecological crisis is accompanied by an ever more obvious failure of the system of international governance. The ability of the entire world population to control ('govern') itself seems at stake now. The question of whether the world is at a tipping point might be rhetorical, but should alert us to an entirely new dimension of the human experience. If it is true that we are about to undermine our own conditions of survival, we must ask what the role of the human species is in the grand scheme of things. Perhaps there is no answer to this question, but common sense would suggest we try harder. If the current system of governance is insufficient, we should have the courage to explore and demand a new or much improved system. In the end, states are mere vehicles of governance, probably overrated and certainly not without alternatives. A multilayered, transnational system of democratic governance based on constitutional principles (such as those expressed in the Earth Charter) may still involve states, but is not dependent on them. It can't be, as any democratic system is accountable only to the demos, neither to states nor corporations nor any other legal constructs.

6 The concern of humanity being in a somehow unhealthy relationship with nature is much older, though. For a history of sustainable thinking in Europe, see Ulrich Grober, Sustainability: A Cultural History (Green Books, Cambridge 2012).

7 The Montreal Protocol (1989) to ban CFCs worldwide could also be mentioned, however the availability of substances to substitute CFCs allowed this treaty to merely codify what economically posed no real challenge; see, for example, Barber and Bartlett (note 2): 97.

8 Johan Rockström et al., 'A Safe Operating Space for Humanity' (2006) Nature, 461, 472; WWF, 'Living Planet Report 2010' (2010): http://assets.wwf.org. uk/downloads/wwf_lpr2010_lr_1_.pdf. 


\section{ECOLOGICAL TIPPING POINTS}

Numerous commentators have argued that the planet is now at an ecological tipping point. A 'tipping point', with respect to the environment, is the point at which the environmental damage wrought upon the earth will cause ecosystems to shift from one state to another, at which time it will be difficult or impossible to return it to the former conditions which have been previously relied upon. ${ }^{9}$ While no one can predict with precise accuracy exactly how close ecosystems are to their tipping points, and how much additional pressure might bring them about, or whether they have already been tipped into another state, what is known is that the present state and trends concerning the environment are creating a perilously dangerous situation. ${ }^{10}$

The effect that humans are having upon the earth has been vividly illustrated by the renowned environmentalist David Suzuki in his book, The Legacy. Suzuki traces the evolution of human life in order to show that until the recent past (relative to a long timescale) the environment of the earth has remained fairly stable. As Suzuki notes, the 'hockey stick' graph of our population explosion (100,000 years to reach a billion, and a mere 200 years to multiply that figure by 6.9), viewed in conjunction with other negative environmental impacts such as carbon emissions, deforestation and biodiversity loss, which all follow the same curvature, paints a frightening picture for our future. ${ }^{11}$ Indeed, with overall unsustainable consumption continuing, the global demand for resources now exceeds the biological capacity of the earth to renew those resources by some 25 percent. ${ }^{12}$ This has meant that "[f]or the first time in the 3.8 billion years that life has existed on Earth one species - humanity - is altering the biological, physical and chemical features of the planet on a geological scale'. ${ }^{13}$

9 Secretariat of the Convention on Biological Diversity, 'Global Biodiversity Outlook 3' (Montreal 2010): 11.

10 For example, the Fifth Assessment Report of the Intergovernmental Panel on Climate Change describes some of the current risks as follows: 'With increasing warming, some physical systems or ecosystems may be at risk of abrupt and irreversible changes (...) warm-water coral reefs and Arctic ecosystems are already experiencing irreversible regime shifts (. . .).' (IPCC, Climate Change 2014: Impacts, Adaptation, and Vulnerability. Summary for Policymakers, Working Group II, at 12; http://www.ipcc.ch/pdf/assessment-report/ar5/wg2/ar5_wgII_spm_en.pdf.

11 David Suzuki, The Legacy (Allen \& Unwin, Crows Nest, NSW 2010): 20.

12 Wolfgang Sachs, Tilman Santarius and Patrick Carniller, Fair Future: Resource Conflicts, Security and Global Justice: A Report of the Wuppertal Institute for Climate and Energy (Zed Books, London 2005): 26.

13 This is often referred to as the shift from the relatively stable Holocene period of the last 10,000 years to the unstable and much more hazardous Anthropocene 
When viewed in this light, it becomes clear that humanity's effect on the earth is not a marginal phenomenon, but literally an earth-changing event with massive implications. The following will give a brief (and not exhaustive) survey of some of the major ecological problems which we find ourselves confronted with as we move into the second decade of the twenty-first century. The ecological crisis finds perhaps its most vivid illustration in the issue of global warming, which has garnered considerable public attention. The issue has been highlighted by numerous prominent scientists and environmentalists and is to date the only environmental issue that has resulted in comprehensive international action. ${ }^{14}$ The scientific evidence affirming global warming is now unequivocal, as was shown by the 2007 Intergovernmental Panel on Climate Change (IPCC), which found that global warming was evident from observations in global average air and ocean temperatures, widespread melting of snow and ice, and rising global average sea level. ${ }^{15}$ This observed increase in temperature was considered 'very likely' ( 90 percent certainty) to have been induced by human causes. ${ }^{16}$ The 2014 IPCC report rates this as 'extremely likely' (95-100 percent certainty). ${ }^{17}$

It is important to note that climate change is not merely a future risk, but a phenomenon which is affecting millions of lives already. In fact, a report issued by the Global Humanitarian Forum found that climate change affects 325 million people each year. ${ }^{18}$ As the problem escalates, the number of those seriously affected by climate change is expected to more than double within 20 years. ${ }^{19}$

period where humans have had a profound impact upon the earth. David T. Suzuki, Amanda McConnell and Adrienne Mason, The Sacred Balance: Rediscovering Our Place in Nature (Allen \& Unwin, Crows Nest, NSW 1997): 11; Paul Crutzen and Eugene Stoermer, The 'Anthropocene' 41 (2000) Global Change Newsletter 17-18.

${ }_{14}$ Kyoto Protocol to the United Nations Framework Convention on Climate Change FCCC/CP/1997/7/Add 1 (1997).

15 S. Solomon, D. Qin, M. Manning, Z. Chen, M. Marquis, K.B. Averyt, M. Tignor and H.L. Miller (eds), Climate Change 2007: The Physical Science Basis Contribution of Working Group I to the Fourth Assessment Report of the Intergovernmental Panel on Climate Change (Cambridge University Press, Cambridge 2007): 8. See also Naomi Oreskes, 'Beyond the Ivory Tower: The Scientific Consensus on Climate Change' (2004) 306 (5702) Science 22, which found that out of over 9000 journal abstracts analysed dealing with climate change none refuted the argument that global warming is occurring.

16 Ibid.: 17.

17 Fifth Assessment Report (note 10) at 15.

18 'Human Impact Report: Climate Change - The Anatomy of a Silent Crisis' (Global Humanitarian Forum, 2009): 19.

19 Ibid. 
While global warming has been the ecological problem which has garnered the most attention, the empirical evidence illustrates that there has been a rapid deterioration of ecological conditions in almost all biospheres. Indeed, the different biospheres that have been endangered by human action are truly daunting. For example, soil erosion is another area of ecology which, while not having drawn much widespread attention, is in a dire state. As one expert specializing in soil conditions has remarked, '[1]and degradation and desertification may be regarded as the silent crisis of the world, a genuine threat to the future of humankind' ${ }^{20}$ Given the evidence, such remarks do not overstate the case; it is estimated that, overall, soil is being lost from land areas 10-40 times faster than the rate of soil renewal, thereby imperiling future human food, security and environmental quality. ${ }^{21}$ This is a trend which, in conjunction with the cumulative effects of global climate change, is expected to get exponentially worse. ${ }^{22}$ Furthermore, the worsening state of soil erosion will in turn increase the effects of global warming, thus creating a vicious cycle. ${ }^{23}$

Another area of major ecological concern is dwindling biodiversity. The Global Biodiversity Outlook Report has provided a reminder of just how serious the problem is. This report found that species which have been assessed for extinction risk are, on average, moving closer to extinction. For example, nearly a quarter of all plant species are estimated to be threatened with extinction, while trends of some 3,000 wild populations of species show a consistent decline in average species abundance of nearly 50 percent between 1970 and 2010; inland water species have declined by 50 percent, while marine and terrestrial species have both declined by around 35 percent. $^{24}$

Furthermore, loss of biodiversity is a phenomenon which will assuredly worsen with climate change. Indeed, studies are finding that the climate change that has occurred thus far is already having a marked impact upon animal and plant populations, and it is expected that the synergism of rapid temperature rise and other stresses, in particular habitat destruction, will

\footnotetext{
${ }^{20}$ Andres Arnald quoted in Stephen Leahy, 'Peak Soil: The Silent Global Crisis' (2008) 23 (1) Earth Island Journal 58.

${ }_{21}$ David Pimentel, 'Soil Erosion: a Food and Environmental Threat' (2006) 8 (1) Environment Development and Sustainability 119.

22 M.A. Nearing, F.F. Pruski and M.R. O' Neal, 'Expected Climate Change Impacts on Soil Erosion Rates: A Review' (2004) 59 Journal of Soil and Water Conservation 45.

23 R. Lal, 'Soil Carbon Sequestrian Impacts on Global Climate Change and Food Security' (2004) 304 (5677) Science 1623.

24 Secretariat of the Convention on Biological Diversity (note 9): 9.
} 
ultimately result in numerous extirpations and possibly extinctions. ${ }^{25}$ This flow-on effect of climate change is particularly problematic as the contribution of biodiverse ecosystems to human societies promises to become all the more important as environmental change accelerates. This is because biodiverse ecosystems tend to be more resilient and can therefore better cope with an increasingly unpredictable world. ${ }^{26} \mathrm{~A}$ final area of concern briefly to be noted here is the issue of deforestation. Deforestation, mainly through conversion of forests to agricultural land, continues at an alarmingly high rate: the loss of primary forest since 2000 has been estimated at 6 million hectares annually. ${ }^{27}$ In addition, forests and other natural habitats are being increasingly fragmented, affecting their ability to maintain biodiversity and deliver ecosystem goods and services. As is well known, deforestation is also a leading cause of our current climate crisis.

What we can say about these ecological issues is that they are not readily separable, but rather are interlinked with each ecological dynamic feeding into another, ultimately leading to a downward spiral of ecological disintegration. Thus, we can see the immense fragility of ecosystems and the perilousness of the ecological situation with which we are faced. While there are still some gaps in scientific knowledge (indeed, when we are dealing with such complex ecosystems we could hardly expect it to be otherwise), current scientific evidence is converging on consensus: we are facing a massive ecological crisis. It is clear that this 'hockey graph' cannot continue indefinitely; the earth can only sustain this trend for so long. Indeed, if continued unabated, it can well be argued that the end result of this dramatic human impact on the earth will be that we follow a path to our own extinction. While as Suzuki points out there is nothing unique about a species becoming extinct - 99.9999 percent of species that have ever existed are now extinct - humans, unlike other species, are in a unique position in that we alone have the ability to change the future by what we do today. ${ }^{28}$

But will it not all be too late? The evidence of planetary ecological decline caused by humans is overwhelming. Furthermore, leaders in government and business are not denying the evidence. Only in extreme cases

25 Terry Root et al., 'Fingerprints of Global Warming on Wild Animals and Plants' (2005) 421 Nature 57.

26 Rob Roggema, Adaptation to Climate Change: A Spatial Challenge (Springer, Berlin 2009): 232.

27 'State of the World's Forests' (Food and Agriculture Organization of the United States, 2007): 64.

28 David Suzuki, David Suzuki: The Autobiography (Greystone Books, Vancouver, BC 2007): 398. 
do we see fundamentalists - in politics, religion or business - talking down climate change or biodiversity loss as a threat to humanity. The problem is not lack of awareness, but lack of action. We allow the ecological decline to take its course without any attempt at stopping it. The defining problem of Western civilization seems to be its incapacity to act, despite knowing what is going on and what will happen next. Unlike previous civilizations such as the Roman or Mayan empires which collapsed as a result of ignorance, current Western civilization has sophisticated technological means to predict the consequences of its actions. Just how much we know is staggering, but even more astonishing is our inability to act upon what we know.

Perhaps the most striking example of inertia is that precisely at a time when the transition to renewable energy becomes realistic and palpable, the world production of greenhouse gases is on the increase. Indeed, energy transition is often seen as an opportunity to get even more oil, gas and coal out of the ground, no matter how costly (fracking, deep-seabed mining, large-scale open mining). The motives behind such behaviour resemble hysteria and paranoia.

In classical physics, as formulated by Isaac Newton, the law of inertia states that an object will stay at rest or stay in motion unless acted on by external forces. In human life, inertia describes the resistance to motion or action either for physical or for psychological reasons. Most of us occasionally experience a lack of initiative or traits of remaining inactive despite a strongly felt need to do something that needs to be done. This can lead to some strange behaviour: just to put off working on a project that we see as daunting, we go to great lengths to find excuses for doing more of the same or something different, as long as we are not 'forced' into actually beginning the project. The more we are locked into this kind of inertia, the more it becomes paradoxical in the sense of being self-contradictory and counterproductive. The paradox of inertia then is a state of paralysis where a situation worsens through deliberate avoidance.

In normal life, the paradox of inertia is often broken when a critical incident occurs: the classic learning-by-mistake experience; an unexpected marriage breakdown after years of not wanting to see the writing on the wall; a heart attack that puts someone on track for a healthier life only after years of avoiding nutritious food and exercise; or the lung cancer that finally causes the addict smoker to quit and pursue the 'good life'.

It may well be that, collectively, we will have to wait for the critical incident - the collapse of civilization - before being ready for change. Obviously, we won't know until it is too late. The paradox of inertia is well worth exploring further though. Arguably, it can also be broken by fully 
understanding what is going on and actually wanting to do what needs to be done.

\section{POLITICAL TIPPING POINTS}

One paradox we can observe is the process of ever increasing numbers of democracies while simultaneously seeing a general decline in democracy.

The last few decades have seen a remarkable turn towards democracy. Qualitative data show that 120 sovereign states out of 192 are democratic, embracing 58 percent of the world's population. ${ }^{29}$ This turn to democracy has led one political philosopher to declare that 'democracy is the only regime most living humans now deem worthy of serious consideration, exploration, clarification, articulation, exportation, importation, and finally faith'. ${ }^{30}$ Yet alongside democratization has been the advent of globalization which has had a marked impact on the ability of states, and the citizens they represent, to exercise control over their financial, social and environmental affairs. The globalization process has meant that the sheer scale of 'contemporary social and economic change appears to outstrip the capacity of national governments or citizens to control contest or resist that change. Thus the limits of national politics are forcefully suggested by globalization'. ${ }^{31}$ Citizens in countries as diverse as Brazil to Tanzania, to Samoa or Greece, feel that they are being swept up in a tide of change over which they have little control and often no voice.

The declining power of states to regulate their affairs can, in large part, be attributed to the spread of neo-liberal economics. This is because neoliberal economic policies such as free trade and the liberalization of markets, while held to be the key to nation-state independence through increased prosperity, in reality serve to usurp power from governments. A striking example of how free-trade agreements have the potential to restrict the sovereignty of governments can be found in the proposed Transatlantic Trade and Investment Partnership (TTIP) between North America and Europe $^{32}$ and the proposed Transpacific Trade Partnership (TPP) between

29 Danille Archibugi, 'Demos and Cosmopolis' (2002) 13 New Left Review 27.

30 Patrick J. Deneen, Democratic Faith (Princeton University Press, Princeton, NJ 2005): xvi.

31 David Held, Global Transformations: Politics, Economics and Culture (Stanford University Press, Stanford, CA 1999): 1.

32 John Hilary (ed.), The Transatlantic Trade and Investment Partnership (TTIP): A Charter for Deregulation, an Attack on Jobs, an End to Democracy 
North America, South East Asia and Oceania. ${ }^{33}$ The key proposals in each of these agreements would guarantee foreign investors the right to comment on proposed new laws that affect their operations, thereby giving foreign companies more say over regulations than the voters in the countries in which the companies reside. Furthermore, these proposals would result in foreign corporations having the power to take governments to international arbitration, in order to claim compensation for implementing regulations that have reduced the value of their investment. Such agreements 'deliberately close off the ideological and legal space for governments to give priority to social needs and the common good over "trade" commitments or even to respond to a disabling political crisis. States are relegated to a self-limiting and "enabling" role vis-a-vis capital'. ${ }^{34}$

More generally, the sovereignty of governments has been reduced by vast privatization schemes, which have resulted in the private sector performing the services that had previously been the prerogative of the state. Privatization of public services leaves a government's hands tied and makes putting into effect policies that may have a negative effect on the market all but impossible. As nation-states have scurried to fulfil the vagaries of the market, any other concerns, such as inequality or deleterious environmental impacts, are marginalized. In effect, this has resulted in much power being wrested from the public majority to be held in very few hands. Thus, neoliberal economics has diminished the capacity of democracy to function according to the dictates of the public. Commenting on the democratic nature of the neoliberal age, Jane Kelsey asserts 'a sterile spectator-style of democracy where the responsibility to govern is entrusted to political leaders and "voices of the market". Citizens are informed of decisions, often ex post-facto, but not actively involved in making them' ${ }^{35}$

Furthermore, under the current system those who are facing the worst impacts of environmental degradation rarely have a voice over the practices which are jeopardising their present and even more so their futures. The fact that those who have been forced to suffer the brunt of

(Rosa Luxemburg Stiftung, Brussels 2014): http://rosalux-europa.info/userfiles/ file/TTIP_EN.pdf.

33 Jane Kelsey (ed.), No Ordinary Deal: Unmasking the Transpacific Partnership Free Trade Agreement (Allen \& Unwin, Sydney 2010).

34 Jane Kelsey, Serving Whose Interests? The Political Economy of Trade in Services Agreements (Routledge, London 2008): 319; see also Jane Kelsey, The FIRE Economy (Bridget Williams Books, Wellington, NZ 2015).

35 Ibid. 
our declining environment are also marginalized politically is no mere coincidence. Rather, with the globalization of neo-liberal economics, wealthy states have often been able to export some of the worst environmental effects to the developing world. ${ }^{36}$ Accordingly, the green political challenge raised by the ecological crisis involves the double challenge of not only finding ways of reducing ecological and social risks wherever possible, but also finding ways of minimizing the unfair externalization and displacement of risks onto innocent third parties in space and time. ${ }^{37}$

The impact of neo-liberal policies has been illustrated by the last economic crisis. As is well known, in 2008 the global financial system came to the brink of collapse due to the housing bubble, subprime mortgages, securitization, a lack of government regulation and oversight and greed. The stock markets, which were at or near their all-time peaks in late 2007, came tumbling down, with the DOW Jones Industrial Average falling to a 12-year low by early $2009 .{ }^{38}$ The result was an economic recession which rivalled that of the Great Depression. ${ }^{39}$ The impact of this economic collapse was particularly hard felt in countries such as Iceland, which had grown rich through the types of investments that collapsed, but even more so in countries such as Greece, Portugal and Spain, which were forced into strangling austerity measures by the Eurozone's rich countries.

This economic meltdown has been illustrative of the fact that neoliberal economic policies have undoubtedly failed. The reactive character of bailing out measures - unaccompanied by regulatory reforms - demonstrated that governments are at the mercy of financial institutions rather than controlling them. ${ }^{40}$ As citizens saw their governments rescue the financial giants who created the very disasters for which they were now paying, they began to wonder who actually benefits from the current economic system. More and more people feel that something has gone

36 See Wolfgang Sachs, Planet Dialectics: Explorations in Environment and Development (Zed Books, London 1992).

37 Robin Eckersley, 'Deliberative Democracy, Ecological Representation, and Risk: Towards a Democracy of the Affected', in Graham Smith (ed.), Democratic Innovation, Deliberation, Representation and Association (Routledge, London 2000).

38 Peter A. McKay, 'DOW is Off 7, 401.24 Points from its Record High in '07', The Wall Street Journal (3 March 2009): http://online.wsj.com/article/ SB123599406229708501.html.

39 'Riots Rock Greece as Thousands Take to the Streets', Huffington Post (3 November 2010): http://www.huffingtonpost.com/2010/03/11/riots-rock-greeceas-thou_n_495203.html.

40 Klaus Bosselmann, 'Values for Governing Ourselves: the Earth Charter' (2011) 4 Indigo 112. 
dreadfully awry with our economic system and that the status quo cannot continue for much longer. ${ }^{41}$

The economic crisis has thus become more than a matter of economics; it is merging into a social and political crisis as citizens experience a serious disconnect between themselves and those who represent them.

From this vantage point, neoliberal economics can be seen as a root cause not only of the recent economic crisis, but of the ecological and political crises as well. Indeed, as the effects of the ecological damage which we have wrought upon our planet becomes more and more palpable, neo-liberal economics is increasingly out of sync with the interests of the majority of the world's citizens. The price of continuing the status quo is therefore escalating and if there is to be any hope of addressing the crises with which we find ourselves confronted, we need an approach to politics which is mindful not only of the dictates of the market, but of environmental and social concerns as well. ${ }^{42}$ Needs of the market and needs of society are not the same and must be carefully separated. ${ }^{43}$ The fact that governments have increasingly neglected this separation points to a crisis of democracy. Quite obviously, it is not in the interest of the 'demos' if governments allow markets to determine the direction, scope and content of public policies. Democratic process 'requires that citizens decide all issues that are politically decidable' ${ }^{44}$

While the democratic control of national governments is being hollowed out by the globalization of neo-liberal economics, the international arena also operates in an undemocratic fashion, perhaps most glaringly illustrated by the existence of the Security Council, and the vastly unequal power exercised by states within the UN. Within this power paradigm, states in the developing world are marginalized and their concerns sidelined, and as states continue to act according to the dictates of their own self-interest and are primarily motivated by economic and security concerns, prospects for consensus on ecological issues are undermined. International climate change negotiations provide an all too vivid

${ }^{41}$ See Roger Boyes, 'World Agenda: Riots in Iceland, Latvia and Bulgaria are a Sign of Things to Come', Times Online (21 January 2009): 21: http://www. timesonline.co.uk/tol/news/world/europe/article5559773.ece.

42 Halina Ward, 'One World: Democracy and Sustainable Development' (Presentation to Salzburg Global Seminar Boar Weekend, Salzburg, June 2009).

43 Klaus Bosselmann, Peter Brown and Brendan Mackey, 'Enabling Flourishing Earth: Challenges for the Green Economy, Opportunities for Global Governance' (2012) 21 (1) Review of European Community and International Environmental Law 20-38.

44 Wheatley (note 1): 2. 
illustration of states' unwillingness to make sacrifices for the common good. Yet the processes of globalization and the fact that we all share only one world mean that the strengthening of the international arena in a democratic fashion is not only desirable, but simply necessary. As Falkman has noted, '[n]ow the lines between national and international policy have begun to blur. What is in the national interest when truly seen, merges naturally into the international interest'. ${ }^{45}$ In particular, the common interest of our shared environment on which we all depend makes an internationally coordinated response essential.

As these crises have shown, governments and big businesses acting on their own are unable to respond to the issues of the twenty-first century. Current institutions based on the concerns of nations acting in their own self-interest are insufficient to accommodate more democratic forms of decision-making. Therefore, we are in need of a new approach to governance both at the domestic and international levels. The following sections are concerned with exploring institutions of governance that are firmly grounded in the principles of sustainability, democracy and good governance.

\section{SOCIETIES' RESPONSES SO FAR}

Considering the deepening and seemingly unstoppable ecological crisis, we may well ask whether human society behaves in an irrational or unreasonable manner. 'Irrational' here is used for a society that ignores scientifically proven risks to its own flourishing and continued existence. 'Unreasonable' characterizes a society that is responding to identified risks, but in an inappropriate manner.

Can society act irrationally? On a personal level, we would consider someone who persistently ignores his or her condition, say their rapidly deteriorating health, to be irrational. But what if a whole group of people or society in general behaves in such a manner? What if we let ourselves and our governments conduct business-as-usual knowing that only major change would protect us from demise? We could consider irrational behaviour of society here, but this presupposes actual and sufficiently clear knowledge that is being ignored. More often than not, we hear that environmental problems are difficult to quantify. Unlike markets that are measured on a daily basis and with great detail, environmental conditions

$45 \quad$ K. Falkman (ed.), To Speak for the World: Speeches and Statements by Dag Hammarskjold (Atlantis, Stockholm 2005): 143. 
can only be estimated. This is partly due to an actual lack of available data, but also due to the principle problem of not clearly knowing what to look for. When is an ecosystem healthy or what exactly would it take to restore deteriorating ecosystems to the level of health required by society? There are a lot of unknowns and intangibles here, including the fact that we are notoriously slow at detecting environmental problems, and where they are detected their hard-hitting consequences may only be felt when it is too late.

The solution that most Western societies have given themselves to respond to inevitable environmental uncertainties is the precautionary approach. Better safe than sorry. Yet, while variations of the precautionary principle are part and parcel of modern environmental policy and law, they are not entrenched constitutionally or otherwise, so are ineffective. ${ }^{46}$ The many shortcomings of the precautionary principle are ultimately due to the fact that environmental policy and law themselves are not 'entrenched' and at the centre of society's attention. Rather, they operate at the periphery and are unrelated to the overarching concern for economic growth. ${ }^{47}$ This automatically makes empirical data about the state of the environment less urgent and less relevant than data about the state of the economy. Given such imbalances, deeply embedded in society, it is difficult for politicians to take leadership of and give priority to, not to mention act upon, environmental concerns.

Seeing the economy as more important than the environment may in itself be irrational, but this does not mean that society acts irrationally. The reason for this is the diversity of viewpoints and values that exist despite society's perceived fixation with economics. Diversity of viewpoints is also the reason why societies as a whole are less likely to experience complete inertia, as described earlier. While power elites in government and business may well suffer from the paradox of inertia - and being in the hands of these power elites means that we all suffer - the diversity of viewpoints remains our greatest resource.

It is crucial therefore to realize the potential for change. Like any change, social and political change is determined by the dynamics of active and passive forces. If active forces ('activists') find sufficient resonance amongst other members of society and those in power, then change will occur. The actual chances of this occurring for activists depends on many

46 Klaus Bosselmann, The Principle of Sustainability: Transforming Law and Governance (Ashgate, Farnham 2008): 60, 87-88.

47 Klaus Bosselmann, When Two Worlds Collide: Society and Ecology (RSVP, Auckland 1995): 125-126. 
factors, but more than anything on their ability to communicate in a way that resonates with others. The chance to get the environmental message across is good, precisely because it is a rational and urgent message. What could hinder this, however, is a lack of effective communication channels. This goes to the core of modern liberal democracies. To what extent are they capable of maintaining effective communication channels?

An open, democratic process of debate is not only useful, it becomes an indispensable prerequisite for initiating the kind of social change required for long-term sustainability. How else could the various levels and sectors of society embrace such structural change? One option of course is ruling by decree, as typically in dictatorial regimes. In theory, democratic process can be seen as inferior to dictatorial leadership. In practice, this is not likely to happen as the knowledge required for society to be successful is unlikely to reside with a small elite group of leaders. At least, history has proven this not to be the case. In complex systems such as social organizations, it is more promising to build upon a multitude of contributors to knowledge when reaching decisions. This makes knowledge and subsequent decisionmaking more robust than acting upon shaky or assumed evidence. In addition, open, participatory democracies create active citizens (who in turn create more openness and participation).

In conclusion, a society can only be called irrational if it won't start processes of pondering the political implications drawn from the empirical ecological data. In this sense, the current processes of discussing ways to respond to the ecological crisis at local, national and international level can hardly be described as irrational. We do have debate and plenty of it. The amounts of political and legal documents produced as a result of debates demonstrate that there has been an involvement of societies in the empirically gained data on our ecological situation. The question, however, remains of whether this involvement has led to anything tangible. As the ecological debate has been taking place for more than 40 years ${ }^{48}$ and as the threatening aspects of the ecological crisis are clear to see for everyone, it must be asked whether humanity's response has in fact been adequate and reasonable.

Acting unreasonably is less harmful than acting irrationally. As mentioned, reasonableness refers to the question of whether the actions that are taken or envisaged are sufficient to solve the problem. If we assume - optimistically or not - that societies are acting in a rational fashion, then we need to further ask what it takes to reach a solution to a

48 Assuming a beginning at the 1972 Stockholm Conference on the Human Environment. 
perceived problem. Modern societies have institutional arrangements for solving environmental problems. No government without some kind of ministerial portfolio for the environment; no international legal document without mentioning the importance of protecting the environment; and no supranational institution can claim credibility without giving the environment some special emphasis.

Yet, the ecological crisis continues to worsen as if none of those governmental activities and commitments ever occurred. This situation draws the effectiveness of governance in all its existing forms into question. The way we have been responding to the challenge is in need of a review. Our current practice or 'covenant of reason' 49 seems in need of an overhaul. Is this covenant appropriate for the dimensions we are facing as a result of the ecological crisis? And is it at all reasonable to stick with traditional patterns of problem-solving that appear to drive us deeper and deeper into the crisis?

\section{FAILURE OF LIBERAL DEMOCRACIES?}

The suspicion about our current ways of tackling the ecological crisis just not being appropriate, especially at international level, is growing strongly in the literature..$^{50}$ The current international system emerged in response to some of the most devastating wars humankind has encountered so far. It can be traced back politically to the Westphalian settlement (1648) and philosophically to Hugo Grotius. A second important cornerstone is, of course, the institutional structure of international law and governance following World War II, that is, the UN system. Throughout its existence, however, supra- and international law has maintained the notion of the sovereignty of nation-states. And with it, international diplomacy has followed the liberal perception of trade and exchange as the first means for bridging cultural gaps, promoting prosperity and achieving peace. In the vein of fostering a culture of perpetual peace, as envisaged by Immanuel Kant (1795), the prime focus was on economics. The set-up of the treaties of Rome (1957) creating the European Communities is a striking example of Europe's way of seeking unity through economic harmonization.

If peaceful relations between nation-states have been the ambition of

49 Isaac Levi, The Covenant of Reason: Rationality and the Commitments of Thought (Cambridge University Press, Cambridge 1997); the notion and concept of a 'covenant' have great importance for understanding human relationships, as we will discuss later.

50 For example, Barber and Bartlett (note 2): 63. 
international law, and more recently of supranational law, they were largely determined by economic interests. Military threats to nations and their societies can perhaps be addressed in this way. Wars between European countries and their allies around the globe are less likely today than they have ever been. But what about ecological threats? They affect countries in a more profound way than military threats, not least as the 'enemy' is not 'out there', but within and everywhere. Economic forces won't help as long as they do nothing to address their own ecological dimensions.

The situation we find ourselves confronted with today is unprecedented. It was never considered before in the history of international law. Although steps have been taken to advance the international system in some institutional and legal manner as mentioned, such advances have been modest and totally insufficient. The foundations, principles, structures and processes of international law have hardly been affected..$^{51}$ The principle of the sovereignty of nation-states as stipulated in Art. 2 of the UN Charter, for example, sets limits to the extent of responsibilities that the individual member state has for global affairs. ${ }^{52}$ Characteristically, environmental measures are essentially seen as domestic affairs preventing any interference by other states. ${ }^{53}$ Facing the ever-increasing threats of the ecological crisis might be less a problem of what states eo ipso are willing to do, but more of a problem of the way they have been designed. They are considered to be autonomous ('sovereign') and resting on autonomously acting citizens. The liberal tradition of modern democracies emphasizes individualism over collectivism and individual interests over common interests. From such a perspective, the natural environment appears separate and remote.

One theoretical approach suitable for illustrating this phenomenon

51 An overview of the established institutions is provided by Linda A. Malone and Scott Pasternack, Defending the Environment: Civil Society Strategies to Enforce International Environmental Law (Island Press, Washington, DC 2006): 17; Marvin S. Soroos, 'Global Institutions and the Environment: An Evolutionary Perspective', in Regina S. Axelrod, Stacy D. Van Deveer and David Leonard Downie (eds), The Global Environment: Institutions, Law, and Policy, 3rd edn (CQ Press, Thousand Oaks, CA 2011): 24.

${ }_{52}$ "Nothing contained in the present Charter shall authorize the United Nations to intervene in matters which are essentially within the domestic jurisdiction of any state (...)' (Art. 2, para. 7, Charter of the United Nations).

53 Such limitation even applies within the European Union; see Jürgen Neyer and Michael Schröter, 'Deliberative Europe and the Rejected Constitution', in Erik Eriksen, Christian Joerges and Florian Rödl (eds), Law and Democracy in the Post-National-Union (Arena-Report, Oslo 2006): 61-90. 
is system theory as developed by Niklas Luhmann. ${ }^{54}$ To him, society is defined by its functional difference to its natural environment. This difference is characterized by communication as the mode by which society operates. Thus, society can be understood as the encompassing system of meaningful communication..$^{55}$ A social system interacts with other social systems in an evolutionary process of creating higher complexity. Systems define their boundaries supported by binary codes such as, for example, 'profit/cost' for the economic system or 'rights/non-rights' for the legal system. Through these binary codes, systems constitute themselves inside a process of communicative self-reference, also called autopoiesis. ${ }^{56}$ As a consequence, Luhmann considers society as an operationally closed system of communication only able to deal with itself. For the ecological system this means that autopoietic systems of society have a tendency to ignore or underestimate ecological problems because they are not able, by definition, to communicate with their natural environment. As systems are capable of communicating with each other only through translation and resonance, the process of adopting ecological awareness and knowledge is complex and slow. ${ }^{57}$

While Western liberal democracies may not be well suited for acknowledging ecological challenges, this does not mean that they are incapable of learning. It does mean, however, that international decision-making of states is cumbersome and typically follows a process of negotiation. At the international level, an air of bargaining like independent merchants prevails. This makes conversations in the spirit of humanity awkwardly 'foreign'. The bargaining atmosphere, akin to rational choice and economic rationality, fosters tendencies of shortsighted and selfish results, usually aiming at the lowest common denominator. The binary code of this international system therefore appears as: 'affecting my sovereign interest/not affecting it'. This explains why international systems are

54 Niklas Luhmann, The Differentiation of Society (1982); Benjamin Richardson, 'Trends in North America and Europe', in Klaus Bosselmann, David Grinlinton and Prue Taylor (eds), Environmental Law for a Sustainable Society 2nd edn (NZCEL Monograph Series, 2013): 47-66.

55 Niklas Luhmann, Social Systems (Stanford University Press, Stanford, CA 1995).

56 Niklas Luhmann, Ecological Communication (1986); see also Günther Teubner, Recht als Autopoetisches System (1989) and Benjamin Richardson, 'Trends in North America and Europe', in Klaus Bosselmann, David Grinlinton and Prue Taylor (eds), Environmental Law for a Sustainable Society 2nd edn (NZCEL Monograph Series, 2013): 47, 51.

57 Klaus Bosselmann, When Two Worlds Collide: Society and Ecology (RSVP, Auckland 1995): 153. 
inherently hostile to the idea and needs of participative, transparent and accountable communication, hence the lack of democratic culture and an almost complete absence of the needs of the poor, the natural environment and future generations.

The most fashionable way to communicate the challenges of the ecological crisis is by perceiving them as risks ${ }^{58}$ and, more often than not, perceiving them as economic risks. The normative perspective that serves as a criterion for the risk-measuring process is the precautionary principle. ${ }^{59}$ It therefore does not surprise us that the precautionary principle was mainly developed in reaction to situations of crisis, especially in reaction to food contaminations and irreversible environmental damage. ${ }^{60}$ Although the precautionary principle is supposed to give law a character of risk prevention, its legislative implementation occurred mostly in reaction to major events such as terrorist acts, sudden diseases, nuclear accidents, tsunamis or floods and droughts. This questions the popular reasoning behind the principle often expressed as 'better safe than sorry' (in German: Vorsorgeist besser als Nachsorge, literally: precaution is better than aftercare). If the precautionary principle were taken seriously and applied to actually prevent further environmental deterioration, it would be understood as a rule of fundamental self-constraint that "place(s) the burden of proof on those who argue that a proposed activity will not cause significant harm'. ${ }^{61}$

Defined in this way, the precautionary approach would challenge the assumption of a self-evident prerogative of economic prosperity or social well-being. The problem here is not terminology, but the concepts associated with it. In the prevailing paradigm of economic rationality, prosperity equals growth at all cost, and social well-being or distributive justice are metaphors for access to natural resources no matter how detrimental to the environment. The precautionary approach would challenge, for example, the rationale of the system of international trade under the World Trade Organization (WTO) that considers scientifically proven

\footnotetext{
58 That is why some sociologists describe modern societies as risk societies - see Ulrich Beck, Risikogesellschaft (Suhrkamp, Frankfurt 1986).

59 For example, Björn M. Funke, 'The Precautionary Principle', in Klaus Bosselmann and Ron Engel (eds), The Earth Charter: A Framework for Global Governance (KIT Publishing, Leiden 2010): 191; Birger Arndt, Das Vorsorgeprinzip im EU-Recht (Mohr Siebeck, Tuebingen 2009).

60 Michael W. Schröter, 'Lebensmittelrechtliche Vorsorge als Rechtsprinzip nationale, europäische und welthandelsrechtliche Aspekte', ZERPDiskussionspapier 4 (University of Bremen, Bremen 2002).

61 Principle 6 (b) of the Earth Charter.
} 
risks as relevant purely to human health concerns and only as a matter of risk management (e.g. Art. 5, WTO Agreement on the Application on Sanitary and Phytosanitary Measures). Effectively, such logic places the burden of proof on those who argue that precautionary measures will not cause significant harm to free trade.

Taking this logic to the challenges of the ecological crisis, we encounter two problems. One is the reactionary character of the precautionary principle: it applies only in response to already quantified, widely recognized risks. The other problem is that it overestimates the reliability of science. No environmental scientist can ever provide evidence beyond reasonable doubt; the nature of the beast would simply not allow for such certainty. As a consequence, evidence of risk based on best-available science must suffice to trigger precautionary measures. Fundamentally, we should ask whether we have more trust in the wisdom of precaution or economic cost-benefit analysis.

The debate around global warming gives a warning example. The scientific discovery of human-induced impacts on our climate is over 100 years old. ${ }^{62}$ But, because the system of earth climate is highly complex, the all-encompassing scientific evidence of temporal scales and physical impacts of climate change is still missing, despite consistently growing evidence that climate change is anthropogenic, real and happening now. For more than two decades now, the remaining uncertainties have prevented states from taking definite action. Instead of following a precautionary approach, states have allowed global temperatures to increase to a level where it becomes virtually impossible to reverse current trends to a scientifically acceptable level of 350 carbon dioxide parts per million increase of 1 degree Celsius in average temperatures. We may now be forced into crisis management, trying to cope with impacts, rather than formulating proactive, precautionary measures.

In sum, it is reasonable to suggest that our current ways of problemsolving, although somehow rational, are unreasonable. The predominant rationality seems incapable of responding in a way that can be considered reasonable and effective. This rationality can also be described as the economic rationality of liberal democracies. In the following, we will therefore briefly examine how liberal democracies produce political decisions.

Modern Western-style democracies rely on the political ideology of liberalism. This implies, among other things, the ideas of equality and

62 Compare: 'Fourth Assessment Report, Chapter 1' (2007) IPCC: http://www. ipcc.ch/pdf/assessment-report/ar4/wg1/ar4-wg1-chapter1.pdf (accessed November 2010). 
rule of law. It also alludes to a democratic culture where political power is executed on behalf of the people, perceived as the cumulative will of individuals as the consequence of free and equal elections. That is why some political philosophers consider democracy and liberalism as essentially intertwined. ${ }^{63}$ But there is also a negative aspect of liberalism that continues to feature in the political discourse, that is, the association of liberalism with economic rationality emphasizing individualism and greed over collective responsibilities. ${ }^{64}$ The economic side of liberalism is considered by some to be its very heart, because liberalism aims primarily at self-realization through individual property: freedom becomes a genuine materialistic idea.$^{65}$ As a consequence, liberalism mutates into the opposite of its original purpose: instead of creating free, just and peaceful societies, it keeps generating unjust distributions in favour of an elite in possession of wealth and power at the expense of society and nature ${ }^{66}$ In this manner, liberalism poses a threat to democracy.

How does this influence the manner of problem-solving in liberal democracies? In liberal democracies a procedural approach to truth applies that is highly dependent on plurality. Due to legal equality, everybody has the right to make any claim they wish. This requires a rational mode of communication in which the claim can be evaluated. Applied to political decision-making, this mode requires processes where, ideally, everyone possibly affected by the decision can participate and the result is persuasive in a rational manner for everyone affected. This ideal approach, which deeply inspires a deliberative theory of democracy, ${ }^{67}$ appears to be problematic while trying to respond effectively to the ecological crisis for two reasons. First, due to its procedural character it tends to neglect material influences of truth although they might be vital

63 The best known two are probably John Rawls and Jürgen Habermas.

64 See, for example, C. Crouch, Postdemocrazia (Laterza, Roma/Bari 2003) published as Post-Democracy (Oxford University Press, Oxford 2004); Klaus Bosselmann, The Principle of Sustainability: Transforming Law and Governance (Ashgate, Farnham 2008).

${ }_{65}$ See C.B. MacPherson, The Political Theory of Possessive Individualism (Clarendon Press, Oxford 1962).

${ }_{66}$ This pattern of argument - with variations, of course - is used by many authors and political groups right now and has gathered new intuitive plausibility from the recent financial crisis. In the realm of political philosophy, the criticism of 'atomistic individualism' led, inter alia, to the theoretical approach of communitarism; see, for example, C. Taylor, 'Atomism', in Philosophical Papers Volume 2: Philosophy and the Human Sciences (Cambridge University Press, Cambridge 1985).

67 See Chapter 2.6. 
to society. We will argue below that the ecological crisis constitutes such material truth; and second, those processes tend to be hidden through patterns of rationality claiming to serve social well-being, yet mirror only the shortsighted and selfish interests of some. Insofar as it can be assumed that neo-liberal and pure economic rationality patterns strive to become the rationale of liberal democracies, this calls for developing some ethical approach to the political culture of democracy and the ecological wellbeing of humankind. 